\title{
STRATEGI PEMUNGUTAN PENERIMAAN PAJAK REKLAME KOTA BEKASI
}

\author{
(The Collection Strategy of Advertisement Tax Revenue in Bekasi City)
}

\author{
Aulia Ichsan ${ }^{1}$, Hermanto Siregar ${ }^{2}$, Endriatmo Soetarto ${ }^{3}$
}

\begin{abstract}
${ }^{1}$ Staf Direktorat Jenderal Perbendaharaan, Kementerian Keuangan RI. Email: aulia.ichsan@gmail.com ${ }^{2}$ Staff Pengajar Departemen Ilmu Ekonomi, Fakultas Ekonomi dan Manajemen. IPB. Email: hermansiregar@yahoo.com

${ }^{3}$ Staff Pengajar Departemen Sains Komunikasi dan Pengembangan Masyarakat, Fakultas Ekologi Manusia, IPB Email:endriatmo@yahoo.com
\end{abstract}

\begin{abstract}
One of the efforts of Local Government in financing regional development is through local taxes. Bekasi City is a cross-trade City and its strategic location has great potential to be able to maximize local revenue through the local tax sector, e.g. advertisement tax. The purpose of this research was to determine the growth rate and the contribution of advertisement tax to local taxes, measure the effectiveness and efficiency of advertisement tax, and determine the strategy in the implementation of revenue advertisement tax collections. Analysis methods of this research includes calculation of growth and contribution ratio as well as effectiveness and efficiency ratio and the analytical hierarchy process (AHP). Results of this research show that the growth rate of advertisement tax in Bekasi City average $20.65 \%$ and its contribution to local taxes average of $3.52 \%$ with the average effectiveness rate $82.20 \%$ ("quite effective") and the efficiency level $6.31 \%$ ("highly efficient"). It is suggested from the AHP results that the Local Government of Bekasi City should implement a strategy of improving the quality and quantity of human resources as well as a strategy of improving technical guidelines on advertisement tax collection.
\end{abstract}

Keywords : advertisement tax, growth and contribution, effectiveness and efficiency, strategy, Bekasi City.

\begin{abstract}
ABSTRAK
Salah satu upaya Pemerintah Daerah dalam membiayai pembangunan daerah adalah melalui pajak daerah. Kota Bekasi merupakan kota lintas perdagangan dan lokasinya yang strategis berpotensi besar untuk dapat memaksimalkan pendapatan asli daerah melalui sektor pajak daerah, misalnya pajak reklame. Tujuan dari penelitian ini adalah untuk mengetahui tingkat pertumbuhan dan kontribusi pajak reklame terhadap pajak daerah, mengukur efektifitas dan efisiensi pajak reklame, dan menentukan strategi dalam penerapan pemungutan penerimaan pajak reklame. Metode analisis dalam penelitian ini meliputi rasio pertumbuhan dan kontribusi, rasio efektivitas dan efisiensi dan analytical hierarchy process (AHP). Hasil penelitian ini menunjukkan tingkat pertumbuhan pajak reklame di Kota Bekasi rata-rata 20,65\% dan kontribusi terhadap pajak daerah rata-rata 3,52\% dengan tingkat efektivitas rata-rata $82,20 \%$ kategori cukup efektif dan tingkat efisiensi 6,31\% sangat efisien. Disarankan dari hasil AHP Pemerintah Daerah Kota Bekasi harus menerapkan strategi peningkatan kualitas dan kuantitas sumber daya manusia serta strategi untuk memperbaiki pedoman teknis pemungutan pajak reklame.
\end{abstract}

Kata Kunci: Pajak Reklame, Pertumbuhan Dan Kontribusi, Efektifitas Dan Efisiensi, Strategi, Kota Bekasi

\section{PENDAHULUAN}

Indonesia dalam beberapa tahun terakhir meningkatkan pelaksanaan pembangunan terutama pada bidang ekonomi. Tujuan dari pembangunan adalah untuk meningkatkan pendapatan dan kesejahteraan masyarakat. Pembangunan tidak hanya dilaksanakan oleh Pemerintah Pusat tetapi juga Pemerintah Daerah. Sehingga perlu dilaksanakan desentralisasi pada kewenangan yang disertai juga dengan desentralisasi pada seluruh aspek pemerintah termasuk didalamnya desentralisasi fiskal. Dasar hukum dalam pelaksanaan desentralisasi tersebut dengan diterbitkannya Undang-undang Nomor 33 Tahun 2004 tentang Perimbangan Keuangan antara Pemerintah Pusat dan Pemerintah Daerah 
dan Undang-undang Nomor 23 Tahun 2014 tentang Pemerintah Daerah. Pelaksanaan desentralisasi fiskal ini pada satu sisi memberikan kewenangan yang lebih besar dalam pengelolaan daerah, akan tetapi di sisi lainnya muncul suatu persoalan baru yang dikarenakan tingkat kesiapan fiskal dari masing-masing daerah berbeda-beda (Harianto \& Adi 2007). Dengan tingkat kesiapan fiskal dari masing-masing daerah berbeda, maka mengakibatkan daerah-daerah yang tidak memiliki potensi sumber daya yang cukup akan merasa tidak diuntungkan dengan adanya desentralisasi tersebut (Norregaard 2013). Akan tetapi jika sumber daya yang dimiliki daerah dapat dioptimalkan oleh Pemerintah Daerah, maka dapat memberikan kontribusi pendapatan kepada daerah (Poulson \& Jules 2008). Sehingga dengan begitu diharapkan daerah harus lebih aktif dalam mengotimalkan sumber daya yang ada agar meminimalkan ketergantungan pada sumer dana dari Pemerintah Pusat (Hoque et al. 2008).

Dengan adanya desentralisasi fiskal tersebut, untuk mewujudkan pembangunan pemerintah daerah perlu mengalokasikan dana yang lebih besar untuk dapat mencapai tujuan tersebut. Pendanaan yang dibutuhkan ini dapat diperoleh dengan meningkatkan pendapatan asli daerah. Pendapatan asli daerah merupakan dukungan nyata yang diberikan oleh masyarakat kepada pemerintah daerah untuk melaksanakan pemerintahannya dan juga melakukan pembangunan di wilayahnya (Wibowo 2008).

Pemerintah Kota Bekasi dalam melaksanakan pembangunan juga mempunyai permasalahan dalam pendanaan. Untuk dapat mengatasi permasalahan tersebut, Pemerintah Kota Bekasi menggali potensi yang dimiliki melalui pajak daerah. Pajak Daerah merupakan kontribusi wajib pajak daerah 72 yang terutang oleh orang pribadi atau badan yang bersifat memaksa berdasarkan Undang-undang, dengan tidak mendapatkan imbalan secara langsung dan digunakan untuk keperluan daerah dalam kemakmuran rakyat (Mardiasmo 2002).

Salah satu potensi yang dapat ditingkatkan melalui pajak daerah ini adalah pajak reklame. Pemerintah Daerah Kota Bekasi dalam mendukung penerimaan melalui pajak reklame tersebut menerbitkan Peraturan Daerah Kota Bekasi Nomor 14 Tahun 2012 tentang Pajak Reklame. Selain itu jika dilihat dari sisi geografis, Kota Bekasi mempunyai letak yang strategis sebagai penyangga Ibukota Jakarta dan juga dianggap sebagai jalur lintas perdagangan antar kota sehingga mempunyai potensi dalam melakukan promosi suatu produk serta dengan melihat pesatnya pembangunan pusat perbelanjaan. Dimana secara tidak langsung hal ini akan berakibat pada penerimaan pajak reklame, karena semakin banyak jumlah usaha, maka semakin banyak juga pengusaha yang akan menggunakan jasa reklame. Sehingga dengan begitu pajak reklame akan meningkat dan mempengaruhi jumlah penerimaan pajak daerah. Namun dalam pelaksanaannya pajak reklame dari tahun 2011 - 2015 belum dapat memenuhi target yang ditetapkan sehingga dengan begitu penerimaan pajak daerah melalui pajak reklame ini menjadi tidak optimal.

Berdasarkan uraian di atas tersebut, maka tujuan dari penelitian ini adalah 1) Mengukur tingkat pertumbuhan dan besaran kontribusi penerimaan pajak reklame di Kota Bekasi dari tahun 2011 2015. 2) Mengukur tingkat efektivitas dan efisiensi pemungutan pajak reklame di Kota Bekasi dari tahun 2011 - 2015. 3) Menyusun langkah-langkah strategis dan kebijakan prioritas melaksanakan pemungutan penerimaan pajak reklame di Kota Bekasi. 


\section{METODE PENELITIAN}

\section{Metode Pengumpulan Data}

Penelitian ini menggunakan data primer dan data sekunder. Data primer adalah suatu data yang dikumpulkan dari situasi aktual ketika peristiwa terjadi (Sekaran 2006). Data primer dikumpulkan melalui kuisioner dan wawancara terhadap pihak pemerintah daerah Kota Bekasi sebagai pelaksana pemungutan penerimaan pajak reklame dan perwakilan dari wajib pajak reklame yaitu pengelola dan pengusaha reklame di Kota Bekasi. Data sekunder merupakan suatu sumber data yang tidak langsung memberikan data pada pengumpul data (Sugiyono 2011). Data-data sekunder yang diperlukan oleh peneliti diperoleh dari Badan Pendapatan Daerah Kota Bekasi, Badan Pusat Statistik (BPS) serta dari literatur dan buku yang mendukung penelitian ini. Data-data sekunder yang diperlukan dalam penelitian ini adalah target dan realisasi penerimaan pajak reklame.

\section{Metode Analisis Data}

Dalam penelitian ini, digunakan beberapa metode analisis data yaitu analisis pertumbuhan dan kontribusi, analisis rasio efektifitas dan efisiensi serta analisis perumusan strategi pemungutan penerimaan pajak reklame.

\section{Analisis Pertumbuhan dan Kontribusi Penerimaan Pajak Reklame}

1. Laju Pertumbuhan Penerimaan Pajak Reklame. Analisis ini dirumuskan sebagai berikut (Ratdiananto 2016):

$$
\mathrm{Gt}=\frac{\operatorname{Yr} t-\operatorname{Yr}(t-1)}{\operatorname{Yr}(t-1)} \times 100 \%
$$

Keterangan :

$$
\begin{array}{cl}
\text { Gt } & \text { Tingkat laju pertumbuhan } \\
\text { pajak reklame } \\
\text { Yrt } \quad \text { Realisasi penerimaan pajak } \\
\text { reklame pada tahun tertentu }
\end{array}
$$

Yr (t-1) : Realisasi penerimaan pajak reklame tahun sebelumnya

Dengan dilakukan perhitungan laju pertumbuhan, maka dapat diketahui seberapa berhasilkah Pemerintah Daerah Kota Bekasi dalam melakukan pemungutan penerimaan pajak reklame dengan melihat dari kriteria prosentase keberhasilan pada Tabel 1.

Tabel 1. Kriteria Laju Pertumbuhan

\begin{tabular}{ll}
\hline \multicolumn{1}{c}{ Prosentase } & \multicolumn{1}{c}{ Kriteria } \\
\hline $0 \%-30 \%$ & Tidak Berhasil \\
$30 \%-55 \%$ & Kurang Berhasil \\
$55 \%-70 \%$ & Cukup Berhasil \\
$70 \%-85 \%$ & Berhasil \\
$85 \%-100 \%$ & Sangat Berhasil \\
\hline
\end{tabular}

Sumber : (Halim 2004)

2. Kontribusi Penerimaan Pajak Reklame terhadap Pajak Daerah. Analisis ini dirumuskan sebagai berikut (Ratdiananto 2016):

$$
P=\frac{X n}{Y n} \times 100 \%
$$

Keterangan :

$\mathrm{P}$ : Kontribusi penerimaan pajak reklame

$\mathrm{Xn}$ : Jumlah realisasi penerimaan pajak reklame tahun tertentu

Yn : Jumlah realisasi penerimaan pajak daerah tahun tertentu

Dengan dilakukan perhitungan kontribusi, maka dapat diketahui berapa besar kontribusi yang diberikan pajak reklame terhadap pajak daerah di Kota Bekasi sesuai dengan kriteria prosentase pada Tabel 2.

Tabel 2 Kriteria Kontribusi

\begin{tabular}{ll}
\hline \multicolumn{1}{c}{ Prosentase } & \multicolumn{1}{c}{ Kriteria } \\
\hline $0 \%-10 \%$ & Sangat Kurang \\
$10 \%-20 \%$ & Kurang \\
$20 \%-30 \%$ & Sedang \\
$30 \%-40 \%$ & Cukup Baik \\
$40 \%-50 \%$ & Baik \\
Diatas $50 \%$ & Sangat Baik \\
\hline
\end{tabular}




\section{Analisis Rasio Efektifitas dan Efisiensi Penerimaan Pajak Reklame}

1. Rasio Efektifitas Penerimaan Pajak Reklame

Analisis rasio efektifitas digunakan untuk dapat mengetahui tingkat efektifitas Pemerintah Daerah dalam melakukan pemungutan penerimaan pajak reklame dengan melihat dari total realisasi pajak reklame pada tahun tertentu dibagi dengan target pajak reklame yang telah ditetapkan pada tahun tertentu. Rasio efektifitas ini dirumuskan sebagai berikut (Erawati 2016) :

Tingkat Efektivitas $=\frac{\text { Realisasi Pajak Reklame }}{\text { Target Pajak Reklame }} \times 100 \%$

Dengan dilakukan perhitungan rasio efektivitas, maka dapat diketahui berapa tingkat efektivitas dari penerimaan pajak reklame di Kota Bekasi dengan kriteria prosentase pada Tabel 3.

Tabel 3. Kriteria Efektivitas

\begin{tabular}{ll}
\hline \multicolumn{1}{c}{ Prosentase } & \multicolumn{1}{c}{ Kriteria } \\
\hline Diatas $100 \%$ & Sangat Efektif \\
$90 \%-100 \%$ & Efektif \\
$80 \%-90 \%$ & Cukup Efektif \\
$60 \%-80 \%$ & Kurang Efektif \\
Kurang dari $60 \%$ & Tidak Efektif \\
\hline
\end{tabular}

Sumber : (Mahmudi 2010)

2. Rasio Efisiensi Penerimaan Pajak Reklame

Analisis rasio efisiensi digunakan untuk dapat mengetahui tingkat efisiensi dalam pelaksanaan pemungutan penerimaan pajak reklame oleh Pemerintah Daerah dengan melihat berapa besar biaya pemungutan dibagi dengan berapa berapa besar realisasi dari penerimaan pajak reklame tersebut. Rasio efisiensi ini dirumuskan sebagai berikut (Erawati 2016) :
Efisiensi Pajak Reklame $=$

$\frac{\text { Biaya Pemungutan Pajak Reklame }}{\text { Realisasi Penerimaan Pajak Reklame }} \times 100 \%$

Dengan dilakukan perhitungan rasio efisiensi, maka dapat diketahui berapa tingkat efisiensi dari penerimaan pajak reklame di Kota Bekasi dengan kriteria prosentase pada Tabel 4.

Tabel 4. Kriteria Efisiensi

\begin{tabular}{ll}
\hline \multicolumn{1}{c}{ Prosentase } & \multicolumn{1}{c}{ Kriteria } \\
\hline$<10 \%$ & Sangat Efisien \\
$10 \%-20 \%$ & Efisien \\
$21 \%-30 \%$ & Cukup Efisien \\
$31 \%-40 \%$ & Kurang Efisien \\
$>40 \%$ & Tidak Efisien \\
\hline
\end{tabular}

Sumber : (Mahmudi 2010)

\section{Analisis Perumusan Strategi Pemungutan Penerimaan Pajak Reklame}

Analitycal Hierarchy Process (AHP) merupakan suatu analisis yang memungkinkan kita untuk mengambil keputusan yang efektif atas persoalan kompleks dengan jalan menyederhanakan dan mempercepat proses pengambilan keputusan yang alami (Saaty 1993). Dalam merumuskan strategi kebijakan, kuesioner dan wawancara dilakukan kepada pejabat di Dinas Pekerjaan Umum dan Penataan Ruang Kota Bekasi, Dinas Penanaman Modal dan Pelayanan Terpadu Satu Pintu Kota Bekasi dan Pengusaha serta Pengelolaan Reklame di Kota Bekasi dengan pemilihan sampel secara disengaja. Hirarki yang disusun adalah lima level terdiri atas "Goal" yaitu kebijakan pemungutan penerimaan pajak reklame Kota Bekasi; empat "faktor" yaitu perencanaan pemungutan pajak reklame, fasilitas pendukung kegiatan reklame, sumber daya manusia, tarif dan sistem pemungutan; tiga "pelaku" yaitu Pemerintah Daerah Kota Bekasi, pengusaha reklame, pengelola reklame; lima "kendala" yaitu koordinasi antar unit di Pemerintah Daerah Kota Bekasi, database wajib pajak reklame, pengawasan pengelolaan reklame, 
penegakan hukum pengelolaan reklame, kesadaran dalam perizinan dan pembayaran pajak reklame; dan lima "alternatif strategi" yaitu penertiban petunjuk teknis pemungutan pajak reklame, peningkatan akurasi data potensi pajak reklame berbasis teknologi, peningkatan pengawasan terhadap potensi pajak reklame, peningkatan kualitas dan kuantitas SDM, peningkatan sosialisasi kebijakan pajak reklame. Berikut ini adalah beberapa proses yang harus dilakukan dalam analisis dengan AHP, yaitu sebagai berikut (Ma'arif \& Tanjung 2003):

1. Menentukan permasalahan yang akan diselesaikan berupa sasaran (goal) yang ingin dicapai, faktor/kriteria-kriteria yang akan digunakan, aktor-aktor yang terlibat dalam sistem dan tujuan- tujuannya, dan alternatif-alternatif strategi.

2. Penyusunan hierarki dilakukan dengan mengabstraksi komponen pada sistem. Abstraksi ini harus saling berkaitan, tersusun dari sasaran utama turun ke faktor-faktor, kemudian ke pelaku (aktor), tujuantujuan pelaku, kemudian strategistrategi dan akhirnya memberikan keputusan.

3. Penyusunan matriks pendapat individu untuk setiap kriteria dan alternatif dilakukan melalui perbandingan berpasangan. Setiap elemen sistem dengan elemen lainnya pada setiap tingkat hierarki secara berpasangan dibandingkan untuk memperoleh nilai kepentingan elemen secara kuantitatif.

4. Nilai-nilai perbandingan yang telah dilakukan harus diperoleh tingkat konsistensinya dengan $\mathrm{CR} \leq 10 \%$.

5. Penyusunan matriks pendapat gabungan, kemudian dilakukan pengolahan vertikal untuk menentukan vektor prioritas sistem.

\section{HASIL DAN PEMBAHASAN}

Pemungutan pajak reklame yang dilakukan Badan Pendapatan Daerah (BAPENDA) Pemerintah Daerah Kota Bekasi dengan menerapkan satu sistem yaitu official assessment system, dimana sistem ini memberikan wewenang kepada Pemerintah untuk melakukan perhitungan dari jumlah besaran pajak terutang yang akan dibayarkan oleh wajib pajak.

\section{Kinerja Pemungutan Penerimaan Pajak Reklame}

Analisis pertumbuhan dan kontribusi serta efektifitas dan efisiensi digunakan untuk mengetahui kinerja dari penerimaan pajak reklame. Dimana hasil dari laju pertumbuhan penerimaan pajak reklame dari tahun ke tahun di Kota Bekasi dapat dilihat pada Tabel 5.

Tabel 5 Laju Pertumbuhan Pajak Reklame Kota Bekasi tahun 2011-2015

\begin{tabular}{cccccccc}
\hline & \multicolumn{2}{c}{$\begin{array}{c}\text { Reklame papan/ Bill board/ } \\
\text { Tahun }\end{array}$} & \multicolumn{2}{c}{ Videotron/ Megatron } & \multicolumn{2}{c}{ Reklame Kain } & \multicolumn{2}{c}{$\begin{array}{c}\text { Total Pajak } \\
\text { Reklame }\end{array}$} \\
& Realisasi (Rp) & $(\%)$ & Realisasi (Rp) & $(\%)$ & Realisasi (Rp) & $(\%)$ \\
\hline 2011 & 16.009 .126 .350 & - & 308.075 .647 & - & 16.317 .201 .997 & - \\
2012 & 15.794 .745 .490 & $(1,34)$ & 393.127 .129 & 27,61 & 16.187 .872 .619 & $(0,79)$ \\
2013 & 23.791 .040 .000 & 50,63 & 525.219 .790 & 33,60 & 24.844 .000 .000 & 50,21 \\
2014 & 28.453 .052 .850 & 19,60 & 743.541 .900 & 41,57 & 29.196 .594 .750 & 20,07 \\
2015 & 32.271 .373 .100 & 13,42 & 756.672 .500 & 1,77 & 33.028 .045 .600 & 13,12 \\
\hline & Rata - rata & 20,56 & Rata-Rata & 26,14 & Rata-rata & 20,65 \\
\hline
\end{tabular}

Sumber data : Data diolah (2017)

Berdasarkan Tabel 5 terlihat bahwa pertumbuhan penerimaan pajak reklame mengalami fluktuasi setiap tahunnya dan bernilai positif dengan rata- 
rata $20,65 \%$ dengan kriteria tidak berhasil. Petumbuhan tertinggi pada pajak reklame dialami pada tahun 2013, dimana Kota Bekasi menjadi target bagi para pengusaha untuk melakukan pemasangan reklame terhadap produkproduknya dikarenakan Kota Bekasi memiliki tarif pajak reklame yang rendah jika dibandingkan dengan Jakarta.
Sehingga pada tahun 2013 pertumbuhan pajak reklame di Kota Bekasi menjadi meningkat dari tahun sebelumnya. Selanjutnya untuk mengetahui berapa besar kontribusi yang diberikan dari penerimaan pajak reklame terhadap pajak daerah dapat ditunjukan dengan analisis kontribusi sebagaimana terlihat pada Tabel 6.

Tabel 6. Kontribusi Pajak Reklame terhadap Pajak Daerah Kota Bekasi

\begin{tabular}{cccc}
\hline Tahun & Realisasi Pajak Reklame (Rp) & Realisasi Pajak Daerah (Rp) & $\begin{array}{c}\text { Kontribusi Pajak } \\
\text { Reklame }(\%)\end{array}$ \\
\hline 2011 & $16,317,201,997$ & $375,978,082,270$ & 4,34 \\
2012 & $16,187,872,619$ & $497,833,031,022$ & 3,25 \\
2013 & $24,316,259,790$ & $723,511,938,746$ & 3,36 \\
2014 & $29,196,594,750$ & $845,771,913,123$ & 3,45 \\
2015 & 33.028 .045 .600 & 1.030 .224 .055 .885 & 3,21 \\
\hline \multicolumn{5}{c}{ Rata-rata } & 3,52 \\
\hline
\end{tabular}

Sumber data : Data diolah (2017)

Berdasarkan Tabel 6 dapat dilihat bahwa pajak reklame mempunyai kontribusi positif di dalam meningkatkan penerimaan pajak daerah di Kota Bekasi dengan rata-rata $3,52 \%$ dengan kriteria sangat kurang, namun pajak reklame ini bukan merupakan penyumbang kontribusi yang utama pada pajak daerah sehingga kontribusi yang diberikan tidak terlalu besar. Dengan diketahuinya laju pertumbuhan dan kontribusi dari pajak reklame, maka untuk mengetahui kinerja dari pelaksanaan pemungutan penerimaan pajak reklame dapat dihitung melalui analisis efektifitas dan efisiensi. Hasil dari tingkat efektifitas pemungutan penerimaan pajak reklame dapat dilihat pada Tabel 7.

Tabel 7. Tingkat Efektifitas Pajak Reklame Kota Bekasi Tahun 2011-2015

\begin{tabular}{cccc}
\hline Tahun & $\begin{array}{c}\text { Realisasi Pajak Reklame } \\
(\mathrm{Rp})\end{array}$ & $\begin{array}{c}\text { Target Pajak Reklame } \\
(\mathrm{Rp})\end{array}$ & $\begin{array}{c}\text { Efektivitas Pajak } \\
\text { Reklame }(\%)\end{array}$ \\
\hline 2011 & $16,317,201,997$ & $16,946,682,000$ & 96,29 \\
2012 & $16,187,872,619$ & $18,762,799,800$ & 86,28 \\
2013 & $24,316,259,790$ & $24,844,000,000$ & 97,88 \\
2014 & $29,196,594,750$ & $40,677,884,000$ & 71,78 \\
2015 & 33.028 .045 .600 & 56.169 .719 .600 & 58,80 \\
\hline \multicolumn{4}{c}{ Rata-rata } \\
\hline
\end{tabular}

Sumber data : Data diolah (2017)

Dari Tabel 7 dapat diketahui bahwa rata-rata dari efektivitas pajak reklame di Kota Bekasi 82,20\%. Ini membuktikan bahwa tingkat efektivitas dari penerimaan pajak reklame di Kota Bekasi dapat dikategorikan cukup efektif. Sehingga dengan begitu dapat dikatakan bahwa kinerja dari Pemerintah Kota Bekasi dalam pemungutan penerimaan pajak reklame sudah cukup efektif.

Dengan diketahuinya tingkat efektifitas dari pemungutan penerimaan pajak reklame, maka analisis selanjutnya melakukan perhitungan terhadap tingkat efisiensi dari pemungutan penerimaan pajak reklame tersebut yang dapat dilihat pada Tabel 8. 
Tabel 8. Tingkat Efisiensi Pajak Reklame Kota Bekasi Tahun 2011-2015

\begin{tabular}{cccc}
\hline Tahun & $\begin{array}{c}\text { Biaya Pemungutan Pajak } \\
\text { Reklame (Rp) }\end{array}$ & $\begin{array}{c}\text { Realisasi Pajak } \\
\text { Reklame (Rp) }\end{array}$ & $\begin{array}{c}\text { Efisiensi Pajak } \\
\text { Reklame (\%) }\end{array}$ \\
\hline 2011 & $847,334,100$ & $16,317,201,997$ & $5,19 \%$ \\
2012 & $938,139,990$ & $16,187,872,619$ & $5,80 \%$ \\
2013 & $1,242,200,000$ & $24,316,259,790$ & $5,11 \%$ \\
2014 & $2,033,894,200$ & $29,196,594,750$ & $6,97 \%$ \\
2015 & 2.808 .485 .980 & 33.028 .045 .600 & $8,50 \%$ \\
\hline \multicolumn{4}{c}{ Rata-rata } \\
\hline
\end{tabular}

Sumber data : Data diolah (2017)

Berdasarkan data Tabel 8 dapat dikatakan bahwa tingkat efisiensi ratarata dari pajak reklame di Kota Bekasi $6,31 \%$. Jika dilihat dari data tersebut dapat terlihat bahwa tingkat efisiensi dari pemungutan penerimaan pajak reklame di Kota Bekasi berada pada kategori sangat efisien dengan perhitungan persentase lebih kecil dari $10 \%$. Sehingga dengan begitu dapat dikatakan bahwa kinerja dari Pemerintah Kota Bekasi dalam melakukan pemungutan penerimaan pajak reklame ini sangat baik. Dimana Pemerintah Kota Bekasi dapat meninimalkan biaya pemungutan pajak dengan memenuhi target yang maksimal.

\section{Strategi Pemungutan Penerimaan Pajak Reklame Kota Bekasi}

Berdasarkan hasil analisis data dari kuesioner AHP diperoleh urutan prioritas strategi yaitu peningkatan kualitas dan kuantitas SDM sebagai urutan pertama dengan nilai $(0,280)$. Diikuti secara berturut-turut penertiban petunjuk teknis pemungutan pajak reklame $(0,210)$, peningkatan sosialisasi kebijakan pajak reklame $\quad(0,178), \quad$ peningkatan pengawasan terhadap potensi pajak reklame $(0,174)$, dan peningkatan akurasi data potensi pajak reklame berbasis teknologi $(0,158)$. Prioritas masingmasing level dapat dilihat pada Gambar 1.

Berdasarkan hasil wawancara dengan narasumber, bahwa untuk sumber daya manusia baik di Pemerintah Kota Bekasi dan juga pengelola serta pengusaha reklame masih perlu ditingkatkan. Dimana bagi Pemerintah Kota Bekasi masih sangat membutuhkan penambahan jumlah pegawai dalam pelaksanaan pemungutan penerimaan pajak reklame serta juga dalam melakukan pelayanan dan pengawasan. Namun tidak hanya dari jumlah pegawai saja akan tetapi dari kualitas pegawai yang sudah ada saat ini juga harus ditingkatkan dalam hal pemahaman petunjuk teknis dalam pelaksanaan pemungutan penerimaan pajak reklame dan dari sisi pengelola serta pengusaha reklame juga harus diberikan pemahaman tentang bagaimana persyaratan yang harus dipenuhi dalam mengurus perizinan dan pemasangan papan reklame sehingga tidak terjadi kesalahan dalam pemahaman perizinan. Dan untuk dapat meningkatkan pemahaman mekanisme yang harus dilakukan oleh para pengelola serta pengusaha reklame tersebut, maka Pemerintah Kota Bekasi harus meningkatkan sosialisasi tentang pajak reklame tersebut. Dan dalam hal melakukan pelayanan dan pengawasan juga harus diciptakan suatu sistem berbasis teknologi. 


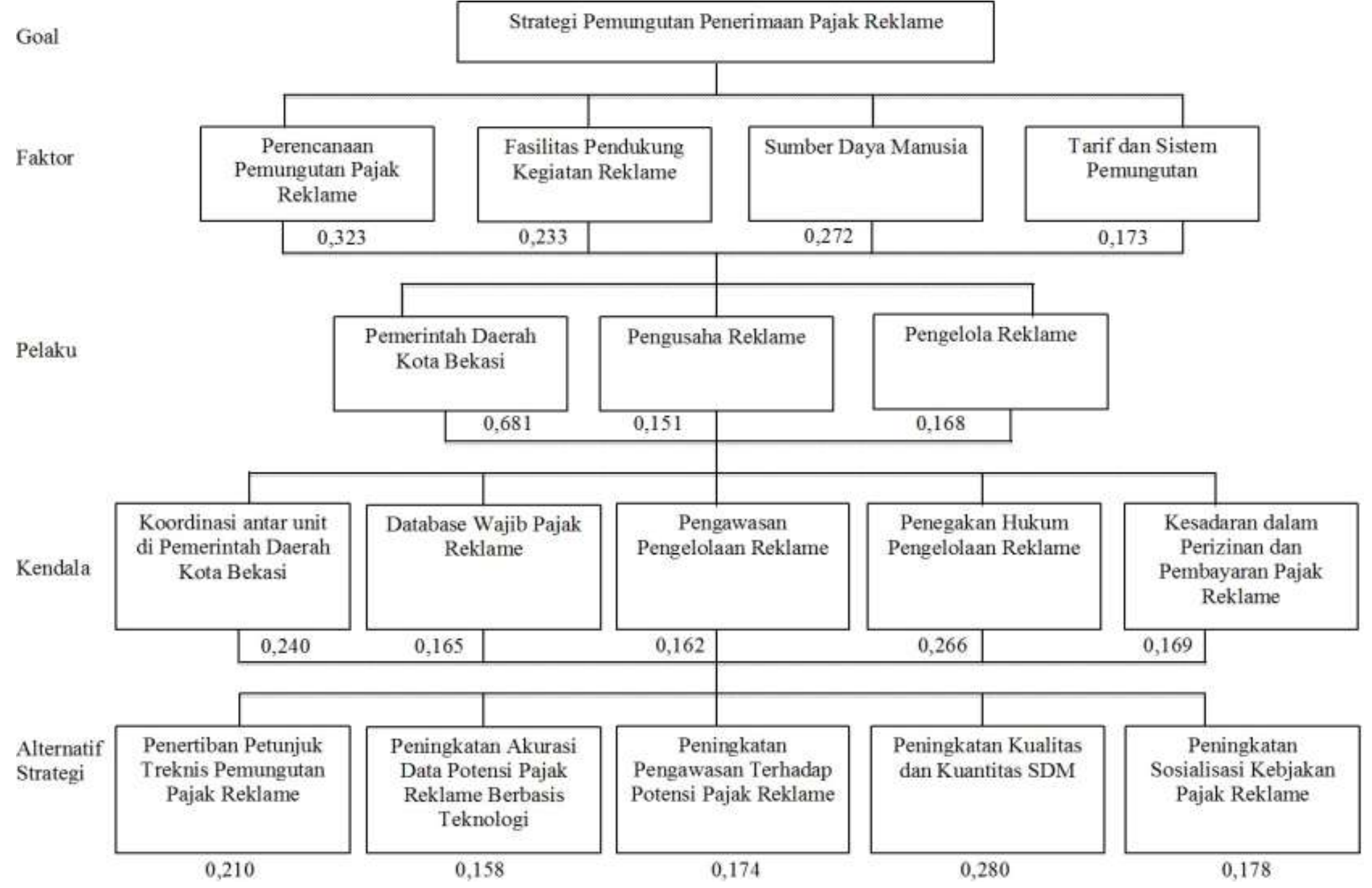

Gambar 1. Hirarki Strategi Pemungutan Penerimaan Pajak Reklame Kota Bekasi 


\section{SIMPULAN DAN SARAN}

\section{Simpulan}

Berdasarkan hasil dan pembahasan yang telah disajikan sebelumnya, maka dapat disimpulkan beberapa hal sebagai berikut:

1. Berdasarkan analisis rasio pertumbuhan dan kontribusi, secara umum dapat digambarkan bahwa kinerja pemungutan penerimaan pajak reklame kurang berhasil. Untuk itu pemerintah daerah Kota Bekasi perlu memperbaiki perencanaan dan pengelolaan pemungutan penerimaan pajak reklame agar dapat menanggulangi permasalahan yang ada, seperti mengurangi kebocoran penerimaan, perhitungan target berdasarkan potensi yang sebenarnya, dan ketegasan petugas pemungut dalam melakukan proses pemungutan dan pengawasan.

2. Menurut rasio efektifitas dan efisiensi, upaya pelaksanaan pemungutan penerimaan pajak reklame yang telah dilakukan oleh pemerintah daerah Kota Bekasi sudah berjalan cukup efektif dan sangat efisien. Namun masih ada beberapa aspek yang perlu segera dilakukan perbaikan yaitu pada sumber daya manusia dan kondisi fasilitas pendukung lainnya.

3. Strategi pemungutan penerimaan pajak reklame Kota Bekasi berdasarkan hasil analisis AHP sesuai urutan prioritasnya yaitu (a) peningkatan kualitas dan kuantitas SDM, (b) penertiban petunjuk teknis pemungutan pajak reklame, (c) peningkatan sosialisasi kebijakan pajak reklame, (d) peningkatan pengawasan terhadap potensi pajak reklame, dan (e) peningkatan akurasi data potensi pajak reklame berbasis teknologi.

\section{Saran}

Beberapa hal yang dapat disampaikan sebagai saran antara lain:

1. Agar Pemerintah Kota Bekasi, khususnya Badan Pendapaan daerah lebih memperhatikan akurasi data wajib pajak dan objek pajak pada pajak reklame bekerja sama dengan asosiasi pengusaha reklame.

2. Dalam melakukan penetapan target yang dilakukan sebelumnya adalah memperhatikan potensi yang sebenarnya sehingga petugas yang terkait akan terpacu untuk melampaui target yang telah ditetapkan.

3. Dalam meningkatkan perolehan pajak reklame agar pertumbuhan dan kontribusi terus meningkat dengan tetap mengutamakan estetika kota dan lebih meningkatkan pelayanan serta pengawasan dalam pelaksanaan pemungutan pajak reklame.

4. Menciptakan suatu sistem yang berbasis teknologi agar koordinasi pelaksanaan pemungutan penerimaan pajak reklame menjadi lebih cepat dan akurat.

5. Memanfaatkan kemajuan teknologi dalam melakukan pemasangan iklan dengan menggunakan media digital dan website Pemerintah Daerah.

\section{DAFTAR PUSTAKA}

Erawati T. 2016. "Analisis Efektifitas dan Efisiensi Pajak Reklame, Pajak Parkir, Pajak Hiburan, Produk Domestik Regional Bruto (PDRB) dan Pendapatan Asli Daerah (PAD) di Kabupaten Bantul." Jurnal Akutansi Vol. 4 No. 1.

Halim A. 2004. Manajemen Keuangan Daerah. Yogyakarta (ID): UPP AMP YKPN.

Harianto D, Adi PH. 2007. "Hubungan 
Belanja Modal, Pendapatan Asli

Daerah dan Pendapatan per Kapita." Simposium Nasional Akuntansi X Makasar.

Hoque, Zahirul, Adams. 2008. "Measuring Public Performance." Goverment Departements In Australia.

Ma'arif MS , Tanjung H. 2003. Manajemen Operasi. Jakarta (ID): Grasindo.

Mahmudi. 2010. Manajemen Keuangan Daerah. Jakarta (ID): Erlangga.

Mardiasmo. 2002. Implikasi APBN dan APBD dalam Konteks Otonomi Daerah dan Manajemen Keuangan Daerah. Yogyakarta (ID): Penerbit Andi.

Norregaard J. 2013. "Taxing Immovable Property: Revenue Potential and Implementation Challenges." IMF Working Paper.

Poulson BW, Jules GK. 2008. "State Income Taxes and Economic
Growth." Cato Journal Vol. 28 No. 1.

Ratdiananto A. 2016. "Analisis Laju Pertumbuhan dan Kontribusi Penerimaan Pajak Reklame Terhadap Pendapatan Pajak Daerah." Jurnal Perpajakan Vol 8 No. 1.

Saaty TL. 1993. Pengambilan Keputusan bagi Para Pemimpin. Jakarta (ID): PT. Pustaka Binaman Pressindo.

Sekaran U. 2006. Metodologi Penelitian Untuk Bisnis. Edisi 4. Jakarta (ID): Salemba Empat.

Sugiyono. 2011. Metode Penelitian Kombinasi. Bandung (ID): Alfabeta Bandung.

Wibowo P. 2008. "Mencermati Dampak Desentralisasi Fiskal Terhadap Pertumbuhan Ekonomi Daerah." Jurnal Keuangan Publik. 
Lampiran : Perancangan program

\begin{tabular}{|c|c|c|}
\hline Strategi & Program & Kegiatan \\
\hline $\begin{array}{l}\text { Peningkatan Kualitas } \\
\text { dan Kuantitas SDM }\end{array}$ & $\begin{array}{l}\text { Program } \\
\text { Pembinaan dan } \\
\text { Pengembangan } \\
\text { Aparatur }\end{array}$ & $\begin{array}{l}\text { 1. Penyelenggaraan bimbingan teknis } \\
\text { pengelolaan pajak reklame. } \\
\text { 2. Tugas belajar dengan jurusan sesuai } \\
\text { kebutuhan organisasi. }\end{array}$ \\
\hline $\begin{array}{l}\text { Penertiban Petunjuk } \\
\text { Teknis Pemungutan } \\
\text { Pajak Reklame } \\
\text { (Raperda) }\end{array}$ & $\begin{array}{l}\text { Program } \\
\text { Penyusunan } \\
\text { Peraturan Daerah }\end{array}$ & $\begin{array}{l}\text { 1. Konsolidasi peraturan petunjuk } \\
\text { teknis pemungutan pajak reklame. } \\
\text { 2. Sosialisasi peraturan petunjuk teknis } \\
\text { ke seluruh unit terkait dalam } \\
\text { pemungutan pajak reklame. } \\
\text { 3. Pelaksanaan peraturan petunjuk } \\
\text { teknis setelah ditetapkan. } \\
\text { 4. Melakukan evaluasi peraturan } \\
\text { petunjuk teknis setelah } \\
\text { dilaksanakan. }\end{array}$ \\
\hline $\begin{array}{l}\text { Peningkatan Sosialisasi } \\
\text { Kebijakan Pajak } \\
\text { Reklame }\end{array}$ & $\begin{array}{l}\text { Program } \\
\text { Intesifikasi } \\
\text { Sosialisasi } \\
\text { Peraturan Daerah }\end{array}$ & $\begin{array}{l}\text { 1. Melakukan sosialisasi peraturan } \\
\text { tentang pajak reklame kepada } \\
\text { pengusaha dan pengelola reklame. } \\
\text { 2. Melakukan sosialisasi peraturan di } \\
\text { SKPD terkait penerimaan pajak } \\
\text { reklame. } \\
\text { 3. Memberikan penyuluhan kepada } \\
\text { petugas pemungut pajak reklame } \\
\text { dan juga para pengusaha serta } \\
\text { pengelola reklame. }\end{array}$ \\
\hline $\begin{array}{l}\text { Peningkatan } \\
\text { Pengawasan Terhadap } \\
\text { Potensi Pajak Reklame }\end{array}$ & $\begin{array}{l}\text { Program } \\
\text { monitoring, } \\
\text { evaluasi dan } \\
\text { permasalahan }\end{array}$ & $\begin{array}{l}\text { 1. Melakukan monitoring terhadap } \\
\text { papan reklame yang terpasang. } \\
\text { 2. Melakukan evaluasi dari penerimaan } \\
\text { pajak reklame. } \\
\text { 3. Melakukan rapat koordinasi } \\
\text { mengatasi permasalahan penerimaan } \\
\text { pajak reklame. }\end{array}$ \\
\hline $\begin{array}{l}\text { Peningkatan Akurasi } \\
\text { Data Potensi Pajak } \\
\text { Reklame Berbasis } \\
\text { Teknologi }\end{array}$ & $\begin{array}{l}\text { Program } \\
\text { pengembangan } \\
\text { sistem informasi } \\
\text { pemungutan }\end{array}$ & $\begin{array}{l}\text { 1. Membangun database maupun } \\
\text { aplikasi sistem pemungutan pajak } \\
\text { reklame. }\end{array}$ \\
\hline
\end{tabular}

